\title{
PERLINDUNGAN KONSUMEN TERHADAP PENJUALAN IPAD TANPA BUKU PETUNJUK BERBAHASA INDONESIA DITINJAU DARI UNDANG- UNDANG NOMOR 8 TAHUN 1999
}

TENTANG PERLINDUNGAN KONSUMEN DAN PERATURAN MENTERI PERDAGANGAN RI

\author{
NOMOR19/M-DAG/PER/5/2009
}

Poltak Siringoringo

Yesika Windasari Butar-Butar

poltaksiringoringo@gmail.com

Universitas Kristen Indonesia, Jakarta, Indonesia

\begin{abstract}
At present the need for electronic goods has become a primary need. There is no denying that electronic equipment helps in human life. Some are used as entertainment tools and some are used as work aids. But there are also those that can be used as well as work tools and entertainment, even educational facilities. This need does not mean insignificant, because as a civilized human being, living in a community is in dire need of various other things that are broader and perfect, both regarding the quality, quantity, and type. It is not surprising then that the industry is rapidly advancing because the level of market needs is quite high, but electronic products include products that have specificity so that not all consumers can know the ins and outs, both capabilities, quality, instructions for use, guarantees / guarantees, after sales service and so on. The fact shows that Indonesia has grown and developed many industrial goods and services, both large and small scale, especially since the implementation of national development in stages and planned through a five-year development plan.
\end{abstract}

Keywords: human life; national develpoment; facilities.

\section{Pendahuluan}

Pada masa sekarang kebutuhan akan barang elektronik sudah menjadi kebutuhan primer. Tidak dapat disangkal bahwa peralatan elektronik membantu dalam kehidupan manusia. Ada yang digunakan sebagai alat hiburan ada yang dimanfaatkan sebagai alat bantu kerja. Tetapi ada juga yang dapat digunakan sekaligus sebagai alat kerja maupun hiburan, bahkan sarana pendidikan. Kebutuhan ini bukan berarti tidak penting, karena sebagai manusia yang berbudaya, yang hidup bermasyarakat sangat memerlukan berbagai hal lain yang lebih luas dan sempurna, baik mengenai mutu, jumlah, dan jenisnya.

Tidaklah mengherankan kalau kemudian industry ini maju pesat karena memang tingkat kebutuhan pasar tergolong tinggi, namun produk elektronik termasuk produk yang memiliki kekhususan sehingga tidak semua konsumen dapat mengetahuiseluk-beluknya, baik kemampuan, kualitas, petunjuk penggunaan, jaminan/garansi, pelayanan purnajual (ketersedi-aan suku cadang) dan lain sebagainya. Kenyataan menunjukkan bahwa di Indonesia telah tumbuh dan berkembang banyak industri barang dan jasa, baik yang berskala besar maupun kecil, terutama sejak dilaksanakannya pembangunan nasional secara bertahap dan terencana melalui rencana pembangunan lima tahun(Repelita).1

Pertumbuhan dan perkembangan industri barang dan jasa di satu pihak membawa dampak positif, antara lain dapat disebutkan: tersedianya kebutuhan dalam jumlah yang mencukupi, mutunya yang lebih baik, serta adanya alternatif pilihan bagi konsumen dalam pemenuhan kebutuhannya. Akan tetapi, pihak terda-pat dampak negatif, yaitu dampak penggunaan dari teknologi itu sendiri serta perilaku bisnis yang timbul karena makin ketatnya persaingan yang mempengaruhi masyarakat konsumen. Konsumen adalah setiap orang

1 Janus Sidabalok, 2010, Hukum Perlindungan konsumen di Indonesia, PT Citra Aditya Bakti, Bandung, h.1-2 
pemakai barang dan/atau jasa yang tersedia dalam masyarakat, baik bagi kepentingan diri sendiri, keluarga, orang lain, maupun mahkluk hidup lain dan tidak untukdiperdagangkan.Para produsen atau pelaku usaha akan mencari keuntungan yang setinggi- tingginya sesuai dengan prinsip ekonomi. Dalam rangka mencapai untung yang setinggi-setingginya itu, para produsen/ pelaku usaha harus bersaing antar sesama mereka dengan perilaku bisnisnya sendiri-sendiri yang dapat merugikan konsumen. Disamping itu, dengan pemahaman bahwa semua masyarakat adalah konsumen, maka melindungi konsumen berarti juga melindungi seluruh masyarakat. Karena itu, sesuai dengan amanat Alinea ke IV pembukaan Undang-Undang Dasar 1945, maka perlindungan konsumen menjadi penting. Lagi pula, jika disadari bahwa konsumen atau masyarakat adalah pelaksana pembangunan yang sekaligus juga sumber pemupukan modal bagi pembangunan, untuk kelangsungan pembangunan nasional mutlak diperlukan perlindungan kepada konsumenitu.

Secara politis perlunya perlindungan hukum bagi konsumen secara umum sudah dinyatakan di dalam Garis-Garis Besar Haluan Negara (GBHN), antara lain melalui Ketetapan MPR RI Nomor II Tahun 1988 dan ketetapan MPR RI Nomor II Tahun 1993, meskipun keduanya memakai istilah yang berbeda, di mana GBHN 1988 Bab IV, Bagian Ekonomi subperdagangan, huruf b dan GBHN 1993 Bab IV bagian F Nomor 8, istilah melindungi kepentingan konsumen. Dari isi GBHN di atas adalah bahwa sudah saatnya konsumen lebih diperhatikan kepentingannya supaya tidak selalu berada di pihak yang dirugikan. Perlindungan atas kepentingankonsumentersebut diperlukan, mengingat bahwa dalam kenyataannya pada umumnya konsumen selalu berada di pihak yangdirugikan.

Dengan demikian, sekurang-kurangnya ada em-pat alasan pokok Perlindungan Hukum Konsumen dilindungi yaitu: melindungi konsumen sama artinya dengan melindungi seluruh bangsa sebagaimana yang diamanatkan oleh tujuan pembangunan nasional menurut Pembukaan Undang-Undang Dasar1945, melindungi konsumen perlu untuk menghindarkan konsumen dari dampak negatif penggunaanteknologi, melindungi konsumen perlu untuk melahirkan manusia-manusia yang sehat rohani dan jasmani sebagai pelaku-pelaku pembangunan, yang berarti juga untuk menjaga kesinambungan pembangunannasional dan melindungi konsumen perlu untuk menjamin sumber dana pembangunan yang bersumber dari masyarakat konsumen.

Berdasarkan pada permasalahan yang diuraikan di dalam latar belakangdi atas, maka disusun rumusan permasalahan sebagai berikut:

1. Bagaimana bentuk perlindungan hukum bagi konsumen terhadap pelaku usaha yang menjual produk IPAD tidak mencantumkan informasi petunjuk penggunaan barang dalam Bahasa Indonesia berdasarkan ketentuan Undang- Undang No.8 Tahun 1999 tentang Perlindugan Konsumen, sedangkan menurut Peraturan Menteri Perdagangan Republik Indonesia Nomor 19/M- DAG/PER/5/2009, IPAD tidak disebutkan sebagai barang yang diharuskan mempunyai petunjuk (manual)?

2. Bagaimana tanggungjawab pelaku usaha terhadap konsumen yang dirugikan akibat IPAD yang dijual tidak terdapat buku manual Bahasa Indonesia menurut Undang-Undang Nomor 8 Tahun 1999 tentang Perlindungan konsumen ?

Adapun tujuan dari penelitian ini adalah untuk menjelaskan mengenai bentuk perlindungan hukum yang diberikan kepada konsumen terhadap pelaku usaha yang menjual produk IPAD tidak sesuai standar dan mutu berdasarkan Undang-Undang Nomor 8 Tahun 1999 tentang Perlindungan Konsumen dan Peraturan Menteri Perdagangan Republik Indonesia Nomor 19/M-DAG/PER/5/2009.

\section{Konsumen dan PelakuUsaha}

Pengertian dari consumer atau consument itu tergantung dalam posisi mana ia berada. Secara harfiah arti kata consumer itu adalah "(lawan dari produsen) setiap orang yang menggunakan barang”. Tujuan peng-gunaan barang atau jasa itu nanti menentukan termasuk konsumen kelompok mana pengguna tersebut. Begitu pula Kamus Bahasa Inggris-Indonesia memberi arti kata consumer sebagai "pemakai atau konsumen.

Istilah lain yang agak dekat dengan konsumen adalah "pembeli" (koper).Istilah ini dapat dijumpai dalam Kitab Undang-Undang Hukum Perdata. Pengertian konsumen jelas lebih luas daripada pembeli. Luasnya 
pengertian konsumen dilukiskan secara sederhana oleh mantan Presiden Amerika Serikat, John F.Kennedy dengan mengatakan, "Consumers by definition include us all" yang berarti definisi konsumen mencakup kita semua. Pakar masalah konsumen di Belanda, Hon-dius menyimpulkan, para ahli hukum pada umumnya sepakat mengartikan konsumen sebagai, pemakai produksi terakhir dari benda dan jasa (uitenindelijke gebruiker van goerden en diensten). Dengan rumusan itu, Hondius ingin membedakan antara konsumen bukan pemakai terakhir (konsumen antara) dan konsumen pemakai terakhir. Konsumen dalam arti luas mencakup kedua kriteria itu, sedangkan konsumen dalam arti sempit hanya mengacu pada konsumen pemakai terakhir. Masalahnya, apakah pengertian konsumen hanya menyangkut orang atau termasuk bukan orang? Di Perancis, berdasarkan doktrin dan yurisprudensi yang berkembang, konsumen diartikan sebagai, "The person who obtains goods or service for personal or family purposes" yang berarti bahwa orang yang memperoleh barang atau jasa untuk tujuan pribadi dankeluarga.2

Pasal 1 Angka 3 Undang-Undang Nomor 8 Tahun 1999 disebutkan pelaku usaha adalah setiap orang perorangan atau badan usaha, baik yang berbentuk badan hukum maupun bukan badan hukum yang didirikan dan berkedudukan atau melakukan kegia-tan dalam wilayah hukum Republik Indonesia, baik sendiri maupun bersama-sama melalui perjanjian menyelenggarakan kegiatan usaha dalam berbagai bidang ekonomi. Pengertian pelaku usaha dalam Pasal 1 Angka 3 Undang-Undang Perlindungan Konsumen cukup luas. Cakupan luasnya pengertian pelaku usaha dalam UUPK tersebut memiliki persamaan dengan pengertian pelaku usaha dalam Masyarakat Eropa terutama Negara Belanda, bahwa dapat dikualifikasi sebagai produsen adalah pembuat produk jadi (finished product), penghasil bahan baku, pembuat suku cadang, setiap orang yang menampakkan dirinya sebagai produsen, dengan jalan mencantumkan namanya, tanda pengenal tertentu, atau tanda lain yang membedakan dengan produk asli, pada produk tertentu, importir suatu produk dengan maksud untuk diperjualbelikan,

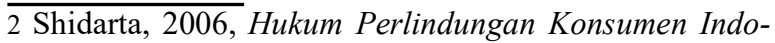
nesia, (Edisi Revisi II, Jakarta, PT.Grasindo), h.2-3 disewakan, disewagunakan (leasing) atau bentuk distribusi lain dalam transaksi perdagangan, pemasok (suplier), dalam hal ini identitas dari produsen atau importir tidak dapat ditentukan Berdasarkan Directive, pengertian "produsen" meliputi:

1. Pihak yang menghasilkan produk akhir berupa barang-barangmanufaktur.

2. Mereka yang bertanggung jawab atas segala kerugian yang timbul dari barang yang mereka edarkan ke masyarakat, termasuk bila kerugian timbul akibat cacatnya barang yang merupakan komponen dalam proses produksinya;

3. Produsen bahan mentah atau komponen suatuproduk;

4. Siapa saja, yang dengan membubuhkan nama, merek, ataupun tanda-tanda lain pada produk menempatkan dirinya sebagai produsen dari suatu barang.

Pengertian pelaku usaha yang sangat luas tersebut diatas, akan memudah konsumen untuk menurut ganti kerugian. Konsumen yang dirugikan akibat mengkonsumsi suatu produk tidak begitu kesulitan dalam menemukan kepada siapa tuntutan diajukan, karena banyak pihak yang dapat digugat. Dalam penjelasan undang-undang yang termasuk dalam pelaku usaha adalah perusahaan, korporasi, BUMN, koperasi, importir, pedagang, distributor dan lain-lain. Sebagai penyelenggara kegiatan usaha, pelaku usaha adalah pihak yang harus bertanggung jawab atas akibat-akibat negatif berupa kerugian yang ditimbulkan oleh usahanya terhadap pihak ketiga, yaitu konsumen, sama seperti seorangprodusen.

\section{Hak dan KewajibanKonsumen}

Pembangunan dan perkembangan perekonomian di bidang perindustrian dan perdagangan nasional telah menghasilkan berbagai variasi barang dan/atau jasa yang dapat dikonsumsi. Ditambah dengan globalisasi dan perdagangan bebas yangdidukung oleh kemajuan teknologi telekomunikasi kiranya memperluas ruang gerak arus transaksi barang dan/atau jasa. Akibatnya barang dan/atau jasa yang ditawarkan bervariasi baik produksi luar negeri maupun produksi dalam negeri. Kondisi seperti ini di satu pihak mempunyai manfaat bagi konsumen karena kebutuhan akan barang dan/ 
atau jasa yang diinginkan dapat terpenuhi serta semakin terbuka lebar, karena adanya kebebasan untuk memilih aneka jenis dan kualitas barang dan/atau jasa sesuai dengan keinginan dan kemampuan konsumen. Tetapi di sisi lain, dapat mengakibatkan kedudukan pelaku usaha dan konsumen menjadi tidak seimbang dan konsumen berada pada posisi yang lemah, yang menjadi objek aktivitas bisnis untuk meraup keuntungan yang sebesar-besarnya oleh pelaku usaha melalui berbagai promosi, cara penjualan, serta penerapan perjanjian baku yang merugikan konsumen. Berkenaan dengan pertimbangan tersebut, maka perlu juga diketengahkan apa yang menjadi hak dan kewajiban konsumen dan pelaku usaha.

Hak konsumen adalah:

- Hak atas kenyamanan, keamanan, dan keselamatan dalam mengkonsumsi barang dan/ataujasa;

- Hak untuk memilih barang dan/atau jasa serta mendapatkan barang dan/atau jasa tersebut sesuai dengan nilai tukar dan kondisi serta jaminan yangdijanjikan;

- Hak atas informasi yang benar, jelas, dan jujur mengenai kondisi dan jaminan barang dan/ataujasa;

- Hak untuk didengar pendapat dan keluhan atas barang dan/atau jasa yang digunakan;

- Hak untuk mendapatkan advokasi, perlindungan, dan upaya penyelesaian sengketa perlindungan konsumen secarapatut;

- Hak untuk mendapat pembinaan dan pendidikankonsumen;

- Hak untuk diperlakukan atau dilayani secara benar dan jujur serta tidak diskriminatif;

- Hak untuk mendapatkan kompensasi, ganti rugi dan/atau penggantian, apabila barang dan/atau jasa yang diterima tidak sesuai dengan perjanjian atau tidak sebagaimana mestinya;

- Hak-hak yang diatur dalam ketentuan peraturan perundang-undangan lainnya3. Secara umum dikenal ada 4 (empat) hak dasarkonsumen:

- Hak untuk mendapakan keamanan (the right tosafety);

3 Indonesia (a) Undang-Undang Nomor 8 Tahun 1999 tentang Perlindungan Konsumen, Pasal 4.
- Hak untuk mendapat informasi (the right to bein-formed);

- Hak untuk memilih (the right tochoose);

- Hak untuk didengar (the right to theheard).

Bagaimanapun ragamnya rumusan hak-hak konsumen yang telah dikemukakan, namun secara garis besar dapat dibagi dalam tiga hak yang menjadi prinsip dasar, yaitu: 1).Hak yang dimaksudkan untuk mencegah konsumen dari kerugian, baik kerugian personal, maupun kerugian harta kekayaan, 2). Hak untuk memperoleh barang dan/atau jasa dengan harga yangwajar, 3) Hak untuk memperoleh penyelesaian yang patut terhadap permasalahan yang dihadapi.

Oleh karena ketiga hak/prinsip dasar tersebut merupakan himpunan beberapa hak konsumen sebagaimana diatur dalam Undang-Undang Perlindungan Konsumen (UUPK), maka hal tersebut sangat esensial bagi konsumen, sehingga dapat dijadikan/merupakan prinsip perlindungan hukum bagi konsumen di Indonesia.

Di samping hak-hak dalam Pasal 4, juga terdapat kewajiban konsumen yang dirumuskan dalam pasalpasal berikutnya. Adapun mengenai kewajiban konsumen dijelaskan dalam Pasal 5, yakni:

- Membaca barang dan/atau jasa, demi keamanan dankeselamatan;

- Beritikad baik dalam melakukan transaksi pembelian barang dan/ataujasa;

- Membayar sesuai dengan nilai tukar yangdisepakati;

- Mengikuti upaya penyelesaian hukum sengketa perlindungan konsumen secara patut.

\section{Hak dan Kewajiban PelakuUsaha}

Dalam Pasal 6 UU No. 8 Tahun 1999, Produsen disebut sebagai Pelaku Usaha yang mempnyai hak sebagai berikut:

1. Hak untuk menerima pembayaran yang sesuai dengan kesepakatan mengenai kondisi dan nilai tukar barang dan/atau jasa yangdiperdagangkan;

2. Hak untuk mendapat perlindungan hukum dari tindakan konsumen yang beritikad tidakbaik;

3. Hak untuk melakukan pembelaan diri sepatutnya di dalam penyelesaian hokumsengketa kon-sumen; 
4. Hak untuk rehabilitasi nama baik apabila terbukti secara hukum bahwa kerugian konsumen tidak diakibatkan oleh barang dan/atau jasa yangdiper-dagangkan;

5. Hak-hak yang diatur dalam ketentuan peraturanperundang-undangan.

6. Hak menerima pembayaran berarti produsenpelaku usaha berhak menerima sejumlah uang sebagai pembayaran atas produk yang dihasilkan dan diserahkan kepada pembeli.

7. Hak mendapat perlindungan hukum berarti produsen-pelaku usaha berhak memperoleh perlindungan hukum jika ada tindakan pihak lain, yaitu konsumen, yang dengan itikad tidak baik menimbulkan kerugian baginya.

8. Hak membela diri berarti produsen-pelaku usaha berhak membela diri dan membela hak- haknya dalam proses hukum apabila ada pihak lain yang mempersalahkan atau merugikan haknya.

9. Hak rehabilitasi, artinya produsen-pelaku usaha berhak memperoleh rehabilitasi atas nama baiknya (dipulihkan nama baiknya) sebagai produsenpelaku usaha jika karena suatu tuntutan akhirnya terbukti bahwa produsen- pelaku usaha ternyata bertindak benar menurut hukum.Terakhir tentang hak-hak yang diatur dalam ketentuan peraturan Perundang-Undangan lainnya, seperti hak-hak yang diatur dalam Undang-Undang Perbankan, Undang-Undang Larangan Praktek Monopoli dan Persaingan Usaha Tidak Sehat, Undang-Undang Pangan, dan Undang-Undang lainnya. Berkenaan dengan berbagai Undang-Undang tersebut, maka harus diingat bahwa Undang- Undang Perlindungan Konsumen adalah payung bagi semua aturan lainnya berkenaan dengan perlindungankonsumen.

Dalam Pasal 7 diatur kewajiban pelaku usaha, sebagai berikut:

1. Beritikad baik dalam melakukan kegiatan usahanya;

2. Memberikan informasi yang benar, jelas dan jujur mengenai kondisi dan jaminan barang dan/ atau jasa serta memberi penjelasan penggunaan, perbaikan, dan pemeliharaan;

3. Memperlakukan atau melayani konsumen secara benar dan jujur serta tidak diskriminatif;

4. Menjamin mutu barang dan/atau jasa yang diproduksi dan/atau diperdgangkan berdasarkan ketentuan standar mutu barang dan/atau jasa yang berlaku;

5. Memberi kesempatan kepada konsumen untuk menguji dan/atau mencoba barang dan/atau jasa tertentu serta memberi jaminan dan/atau garansi atas barang yang dibuat dan/atau yangdiperdagangkan;

6. Memberikan kompensasi, ganti rugi dan/atau penggantian atas kerugian akibatpenggunaan, pemakaian dan pemanfaatan barang dan/atau jasa yang diperdagangkan;

7. Memberi kompensasi ganti rugi dan/atau penggantian apabila barang dan/atau jasa yang diterima atau dimanfaatkan tidak sesuai denganperjan-jian.

Dalam Undang-Undang Perlindungan Konsumen pelaku usaha diwajibkan beritikad baik dalam melakukan kegiatan usahanya, sedangkan bagi konsumen diwajibkan beritikad baik dalam melakukan transaksi pembelian barang dan/atau jasa. Dalam Undang-Un-dang Perlindungan Konsumen tampak bahwa itikad baik lebih ditekankan pada pelaku usaha, karena meliputi semua tahapan dalam melakukan kegiatan usahanya, sehingga dapat diartikan bahwa kewajiban pelaku usaha untuk beritikad baik, dimulai sejak barang dirancang/diproduksi sampai pada tahap pur-napenjualan, sebaliknya konsumen hanya diwajibkan beritikad baik dalam melakukan transaksi pembelian barang dan/atau jasa. Hal ini tentu saja disebabkan oleh kemungkinan terjadinya kerugian bagi konsumen dim-ulai sejak barang dirancang/diproduksi oleh produsen (pelaku usaha), sedangkan bagi konsumen, kemungki-nan untuk dapat merugikan produsen mulai pada saat melakukan transaksi dengan produsen.Pelaku usaha dilarang mencantumkan klausula baku yang letak atau bentuknya sulit terlihat atau tidak dapat dibaca secara 
jelas, atau yang pengungkapannya sulitdimengerti dan setiap klausula baku yang telah ditetapkan oleh pelaku usaha pada dokumen atau perjanjian yang memenuhi ketentuan sebagaimana dimaksud pada ayat(1) dan ayat (2) dinyatakan batal demi hukum, serta pelaku usaha wajib menyesuaikan klausula baku yang ber-tentangan dengan undang-undangini.

\section{Produk Elektronik dan AlatTelekomunikasi}

Teknologi adalah keseluruhan sarana untuk menyediakan barang-barang yang diperlukan bagi kelangsungan dan kenyamanan hidup manusia. Penggunaanteknologi oleh manusia diawali dengan pengubahan sumber daya alam menjadi alat- alat sederhana. Penemuan prasejarah tentang kemampuan mengendalikan api telah menaikkan ketersediaan sumber-sumber pangan, sedangkan penciptaan roda telah membantu manusia dalam perjalanan dan mengendalikan lingkungan mereka. Perkembangan teknologi terbaru, termasuk di antaranya mesin cetak, telepon, dan internet. Telah memperkecil hambatan fisik terhadap komunikasi dan memungkinkan manusia untuk berinteraksi secara bebas dalam skala global4.

Secara umum teknologi dapat didefinisikan sebagai etinitas, benda, maupun benda yang tak diciptakan secara terpadu melalui perbuatan dan pemikiran untuk mencapai suatu nilai. Dalam penggunaan ini teknologi merujuk pada alat dan mesin yang dapat digunakan untuk menyelesaikan masalah-masalah di dunia nyata. Kata "teknologi" juga digunakan untuk meru-juk sekumpulan teknik-teknik. Dalam konteks ini, ia adalah keadaan pengetahuan manusia saat ini tentang bagaimana cara untuk memadukan sumber-sumber guna menghasilkan produk-produk yang dikehendaki, menyelesaikan masalah, memenuhi kebutuhan, atau memuaskan keinginan; ia meliputi metode teknis, keterampilan, proses, teknik, perangkat, dan bahan mentah. Teknologi dapat dipandang sebagai kegiatan yang membentuk atau mengubah kebudayaan. Se-lain itu, teknologi adalah terapan matematika, sains, dan berbagai seni untuk faedah kehidupan seperti yang dikenal saat ini. Sebuah contoh modern adalah

\footnotetext{
4 Muhammad Risal, 2013, Artikel Berita Pengertian Tekhnologi, available from: http:/ www.artikelbagus.com/2013/09/berita-teknologi-pengertianteknologi.html
}

bangkitnya teknologi komunikasi yang memperkecil hambatan bagi interaksisesama manusia, dan sebagai hasilnya, telah membantu melahirkan sub-sub kebudayaan baru; bangkitnya budaya dunia maya yang berbasis pada perkembangan internet dan komputer.

Di dalam Peraturan Menteri Perdagangan Republik Indonesia Nomor 19/M- DAG/PER/5/2009 mengatakan bahwa produk elektronika adalah produkproduk elektronika konsumsi yang dipergunakan di dalam kehidupan rumah tangga. Sedangkan, di dalam Undang-undang No.36 Tahun 1999 tentang Telekomunikasi, Pasal 1 butir 1 menyatakan bahwa telekomunikasi adalah setiap pemancaran, pengiriman, dan atau penerimaan dari setiap informasi dalam bentuk tanda-tanda, isyarat, tulisan, gambar, suara, dan bunyi melalui sistem kawat, optik, radio, atau sistem elektromagnetik lainnya. Dan didalam butir 2 menyatakan yang dimaksud alat telekomunikasi adalah setiap alat perlengkapan yang digunakan dalam bertelekomunikasi. Juga dalam butir 3 menyatakan bahwa perangkat telekomunikasi ialah sekelompok alat telekomunikasi yang memungkinkan bertelekomunikasi. Sedangkan, dan butir 4 menyatakan sarana dan prasarana telekomunikasi adalah segala sesuatu yang memungkinkan bertelekomunikasis.

Petunjuk Penggunaan (Manual) dan Kartu Jaminan/Garansi Purna Jual danKewenangannya

Setiap produk telematika dan elektronika yang diproduksi dan/atau diimpor untuk diperdagangkan di pasar dalam negeri wajib dilengkapi dengan petunjuk penggunaan dan kartu jaminan dalam Bahasa Indonesia.Dan kewajiban penggunaan Bahasa Indonesia sebagaimana dimaksud pada Ayat (1) dapat disandingkan dengan bahasa asing sesuaikebutuhan6.

Petunjuk penggunaan sebagaimana dimaksud da-lam Pasal 2 Ayat (1) harus memuat informasi sekurang-kurangnya mengenai:

1. Nama dan alamat tempat usaha produsen (perusa-haan/pabrik) untuk produk dalamnegeri;

5 Undang-Undang Nomor 36 Tahun 1999 tentang Teleko-munikasi, Pasal 1 Ayat (1) (2) (3) (4)

6 Peraturan Menteri Perdagangan Nomor 19/M-DAG/ PER/5/2009, op.cit, Pasal 2 Ayat (1) (2) 
2. Nama dan alamat tempat usaha importir untuk produkimpor;

3. Merek, jenis, tipe, dan/atau modelproduk;

4. Spesifikasiproduk;

5. Cara penggunaan sesuai fungsi produk; dan

6. Petunjukpemeliharaan.

Produsen atau importir wajib menarik produk telematika danelektronika dariperedaran, apabila:

1. Tidak melengkapi produk telematika dan elektronika dengan petunjuk penggunaan dan kartu jaminan dalam Bahasa Indonesia sebagaimana dimaksud dalam Pasal 2 Ayat (1) dan Pasal 3 Ayat (1), Ayat (2), Ayat (3); atau

2. Petunjuk penggunaan dan kartu jaminan dalam Bahasa Indonesia tidak didaftarkan.

3. Penarikan produk telematika dan elektronika dari peredaran sebagaimana dimaksud pada ayat (1), dilakukan oleh produsen atau importir berdasarkan perintah Direktur Jenderal atas nama Menteri dan seluruh biaya penarikan produk telematika dan eletronika dari peredaran sebagaiamana dimaksud pada ayat dibebankan kepada produsen atau importir.

4. Menteri memiliki kewenangan pengaturan penyelenggaraan pendaftaran, pembinaan, dan pengawasan terhadap petunjuk penggunaan dan kartu jaminan produk telematika dan elektronika. Menteri juga melimpahkan kewenangan sebagaimana dimaksud pada ayat (1) kepada Direktur Jenderal. Direktur Jenderal melimpahkan kewenangan penyelenggaraan pendaftaran petunjuk penggunaan dan kartu jaminan sebagaimana dimaksud pada ayat (2) kepadaDirektur.

\section{Kesimpulan dan Saran}

Perlindungan hukum bagi konsumen atas perbuatan pelaku usaha yang menjual produk Ipad dengan tidak mencantumkan informasi petunjuk penggunaan barang dalam Bahasa Indonesia berdasarkan ketentuan Undang-Undang No.8 Tahun 1999 tentang Perlindugan Konsumen adalah diberikannya sanksi bagi para pelaku usaha yang tidak memberikan informasi yag benar, akurat, relevan, dapat dipercaya, dan yang menyesatkan konsumen sesuai Pasal 62 ayat (1) UU No.8
Tahun 1999 tentang Perlindungan Konsumen yaitu ancaman pidana penjara paling lama 5 (lima) tahun atau dipidana denda paling banyak Rp. 2.000.000.000,00 (dua milyar rupiah). Peraturan MenteriPerdagangan RINo.19/M-DAG/PER/5/2009 tidak secara khusus menyebutkan IPAD, tetapi Ipad adalah produk telematika dan Ipad dapat digunakan sebagai internet, $E$ mail, telepon seluler, facebook, dan kalkulator seperti yang disebut dalam Pasal2 ayat (1). Sehingga sanksi yang dikenakan bagi Pelaku Usaha adalah produsen atau importer wajib menarik produk telematika dan elektronika dari peredaran.

Bentuk pertanggungjawaban yang diberikan oleh pelaku usaha terhadap konsumen yang dirugikan akibat Ipad yang dijual tidak menggunakan petunjuk penggunaanmanualBahasaIndonesiasesuaidenganUndang-UndangNomor8 Tahun 1999 tentang Perlindungan Konsumen adalah bentuk pertanggungjawaban administratif dan/atau perdata sesuaiPasal 60 Un-dangUndang No.8 Tahun 1999 tentang Perlindungan Konsumen, yaitu pembayaran ganti kerugian paling banyak Rp. 200.000.000,00 dan pertanggungjawaban pidana sesuai Pasal 62 Undang-Undang Perlindungan Konsumen.

Peraturan Menteri Perdagangan RI Nomor 19/M-DAG/PER/5/2009 perlu diperbaharui tentang daftar barang yang termasuk tekhnologi agar sesuai dengan perkembangan tekhnologi Informasi dengan rumusan yang tidak limitatif.

Hakim diharapkan berpandangan yang mengutamakan kemanfaatan daripada kepastian hukum sehingga memberi keadilan bagi perlindungan konsumen dalam menggunakan teknologiinformasi.

\section{Daftar Pustaka}

Buku

As'ad Nugroho, Nanang Ismuhartoyo,.Menghadapi

Ketidakadilan Kaum Produsen. Edisi Pertama,

Nopember, Piramedia. 2004

Janus Sidabolok,.Hukum Perlindungan Kon-

sumen di Indonesia . Penerbit: PT. Citra Aditya

Bakti,2010

Husni Syawali, Hukum Perlindungan Konsumen, Mandar Maju, Bandung, 2000 
Tô-râ: Volume 5 Nomor 2, Agustus 2019, Poltak Siringoringo, hal. 83-91

H.Abdurahmat Fathoni, Metode Penelitian \& Teknik Penyusunan Skripsi.Rineka Cipta,Jakarta,2011

Az.Nasution, Hukum Perlindungan Konsumen Suatu Pengantar, Diadit Media, Jakarta, 2001

Shidarta, Hukum Perlindungan Konsumen Indonesia, Edisi revisi kedua, PT.Grasindo,Jakarta,2006

Ahmad Miru dan Sutarman Yodo, Hukum Perlindungan Konsumen, Edisi Pertama, Raja Grafindo Persada, Jakarta, 2001

Celina Tri Siwi Kristiyanti, Hukum Perlindungan Konsumen, Sinar Grafika, Jakarta,2009

Bahder Johan Nasution, BahasaIndonesiaHukum,PT. Citra Aditya Bakti, Bandung,2001

Abdul Halim Barkatulah, Hukum Perlindungan Konsumen Kajian Teoritis dan Perkembangan Hukum, Nusa Media Ujung Berung, Bandung, 2008
PeraturanPerundang-Undangan Undang-Undang Nomor 8 Tahun 1999 tentang Perlindungan Konsumen Ln No.43 Tahun 1999 ILN No. 3821 Tahun 1999.

Undang-Undang Nomor 36 Tahun 1999 tentang Telekomunikasi. Indonesia

Undang-Undang Nomor 24 Tahun 2009 tentangBen-dera, Bahasa,Dan Lambang Negara, Serta Lagu Kebangsaan.

PeraturanMenteri Perdagangan Republik Indonesia Nomor 19/M- DAG/PER/5/2009 Tentang Pendaftaran Petunjuk Penggunaan (Manual) dan Kartu Jaminan/Garansi Purna Jual Dalam Bahasa Indonesia Bagi Produk Telematika DanElektronika. 